\title{
Benign Axillary Neoplasm
}

National Cancer Institute

\section{Source}

National Cancer Institute. Benign Axillary Neoplasm. NCI Thesaurus. Code C35750.

A non-metastasizing neoplasm that arises from the structures of the axilla. 